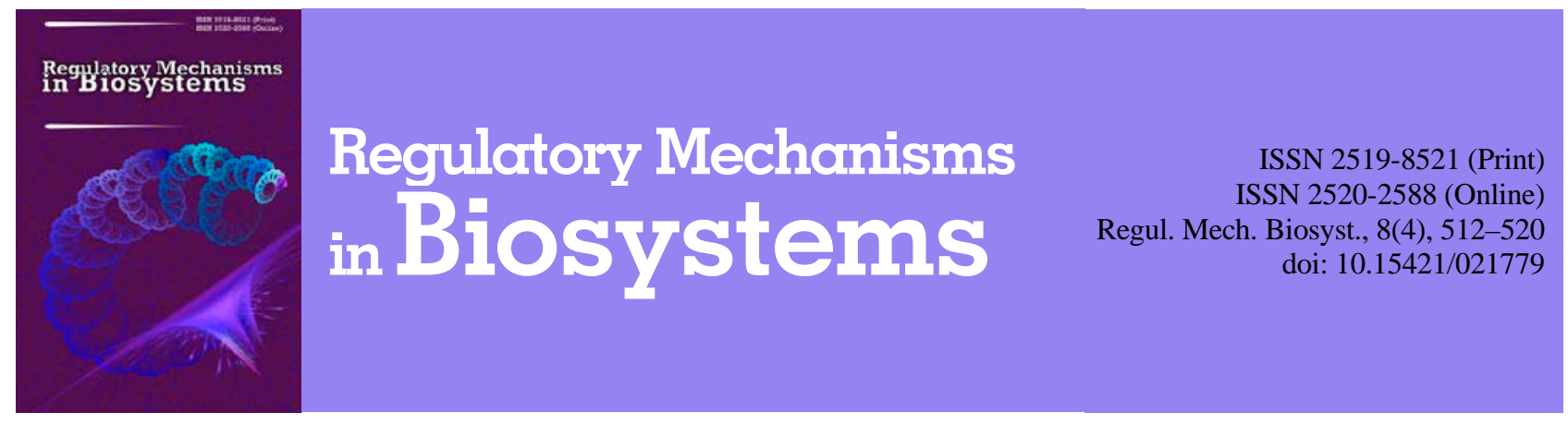

\title{
The role of mitochondria in the myocardium of senescent Meriones unguiculates
}

\author{
Y. Potapenko, O. Dyomshina, G. Ushakova \\ Oles Honchar Dnipro National University, Dnipro, Ukraine
}

Article info

Received 04.10.2017

Received in revised form 10.11.2017

Accepted 13.11.2017

Oles Honchar Dnipro

National University,

Gagarin ave., 72,

Dnipro, 49010, Ukraine.

Tel.: +38-050-607-52-83

E-mail:

olga-d2009@ukr.net

\author{
Potapenko, Y., Dyomshina, O., \& Ushakova, G. (2017). The role of mitochondria in the myocardium of senescent \\ Meriones unguiculates. Regulatory Mechanisms in Biosystems, 8(4), 512-520. doi:10.15421/021779
}

According to the mitochondrial theory of aging, changes in the functional state of mitochondria, which lead to excessive formation of active forms of oxygen, are the main factor in the development of age changes in organs and tissues of the whole organism. The assessment of the mitochondria state of the heart of senescent gerbils (Mongolian Gerbilia, Meriones unguiculates Milne-Edwards, 1867). It is proved that the aging of the heart is preceded by the appearance of dysfunction in mitochondria. The disturbance of metabolic processes in the myocardium of gerbils over the age of two years was established, which was accompanied by activation of oxidative stress by increasing the concentration of TBK-active compounds. An increase in the concentration of cytochrome $\mathrm{C}$ in cytosol has been shown due to the destructive effects of oxidized products on the outer membrane of mitochondria and enhancement of its permeability. The violation of bioenergetic processes, increase of the anaerobic respiration and the accumulation of lactate and unoxidative metabolites, which increases oxidative stress and cell damage, are determined. We established that for gerbils the critical age for senescence is 24 months. Major metabolic changes in the heart occur mostly at this age. This is marked by activation of prooxidants formation, proteolytic processes (decrease in total protein concentration) and inhibition of aminotransferase activity in cytosol. The switching of metabolic processes in the mitochondria of the heart with the participation of aminotransferases has been registered: increased activity of the mitochondrial isoenzyme alanine aminotransferase and reciprocal reduction of aspartate aminotransferase. After two years of age in the experimental gerbils the intensification of adaptive processes was established: activation of catalase, $\gamma$-glutamyltransferase, relative restoration of the activity of alanine and aspartate aminotransferase, thus maintaining the processes of the vital activity of the whole organism, but at a new metabolic level. With age, irreversible damage to cardiomyocytes occurs, which gradually lose the ability to convert lactate, resulting in its increase, and the processes of its utilization are inhibited. The results confirm the key role of mitochondria in the process of aging of the myocardium. However, when gerbils reach the 36 months of age the metabolic disturbances in the myocardium reach their peak, resulting in large-scale cell damage.

Keywords: TBK-active products; superoxide dismutase; catalase; cytochrome C; aminotransferases; lactate dehydrogenase; $\gamma$-glutamyltransferase

\section{Роль мітохондрій міокарда піщанок упродовж фізіологічного старіння}

\author{
Є. О. Потапенко, О. О. Дьомшина, Г. О. Ушакова \\ Дніпровський національний університет імені Олеся Гончара, Дніпро, Украӥна
}

Наведено дані щодо оцінки мітохондрій та біохімічного стану серця монгольських піщанок (Mongolian Gerbilia, Meriones unguiculatus MilneEdwards, 1867) в умовах старіння. Основний фактор розвитку вікових змін в органах і тканинах цілісного організму - надмірне утворення активних форм оксигену, що провокує зміни функціонального стану мітохондрій, зниження ефективності процесу аутофагії / мітофагії. Старінню серця передують появи дисфункцій у мітохондріях. Установлено порушення метаболічних процесів у міокарді піщанок віком старше двох років, що супроводжувалося активацією окисного стресу за рахунок збільшення концентрації ТБК-активних сполук. Доведено збільшення концентрації цитохрому С у цитозолі внаслідок руйнівного впливу окиснених продуктів на зовнішню мембрану мітохондрій та підвищення ії проникності. Визначено порушення біоенергетичних процесів, збільшення частки анаеробного дихання та накопичення лактату й недоокиснених метаболітів, що посилює окисний стрес і пошкодження клітин. Для піщанок переломний вік - 24 місяці. Саме в цьому віці відбуваються основні метаболічні зміни в їхньому серці: активізація утворення прооксидантів, протеолітичних процесів (зниження загальної концентрації протеїну), пригнічення активності амінотрансфераз у цитозолі. Заресстровано переключення метаболічних процесів у мітохондріях серця за участю амінотрансфераз: збільшення активності мітохондріального ізоензиму аланінамінотрансферази та реципрокне зниження аспартатамінотрансферази. Після дворічного віку у дослідних піщанок установлено посилення адаптаційних процесів: активізація каталази, $\gamma$-глутамілтрансферази, відносного відновлення активності аланін- й аспартатамінотрансферази, завдяки чому зберігаються процеси життєдіяльності цілісного організму, але на новому метаболічному рівні. Отримані результати підтверджують головну роль мітохондрій у процесі старіння міокарда. При досягненні віку 36 місяців у міокарді піщанок метаболічні розлади досягають свого піку, що спричинює масштабні пошкодження клітин. Незважаючи на численні дослідження причин старіння серця, участі мітохондрій у даному процесі, біохімічні причини сенесценції потребують подальшого вивчення.

Ключові слова: ТБК-активні продукти; супероксиддисмутаза; каталаза; цитохром С; амінотрансферази; лактатдегідрогеназа; $\gamma$-глутамілтрансфераза 


\section{Вступ}

Старіння - мультифакторний процес, який перебуває під впливом генетики, способу життя та факторів навколишнього середовища, дегенеративний процес, пов'язаний із фізіологічним занепадом, невід'ємна частина життя (Lopez-Otin et al., 2013; Biala et al., 2015; Lakatta, 2015).

Відповідно до мітохондріальної теорії старіння, основний фактор у розвитку вікових змін в органах і тканинах цілісного організму - зміни функціонального стану мітохондрій, що викликає надмірне утворення активних форм оксигену (Judge and Leeuwenburgh, 2007; Marques et al., 2015; Anayt et al., 2017).

Згідно $з$ вільнорадикальною теорією, у процесі старіння відбувається наростання молекулярних пошкоджень мембран i генетичного апарату клітини, послаблення активності захисних механізмів (Josq Maryn-Garcya, 2005; Hayat, 2014; Lekli et al., 2017). Одна 3 основних причин такого явища - інтенсивна генерація активних форм оксигену. Це викликає збільшення дефектів у функціонуванні антиоксидантної системи, фізіологічно спрямованої проти утворення реакційно активних радикальних сполук (Das et al., 2013; Ikeda et al., 2014; Payne and Chinnery, 2015), і як наслідок, спричиняє накопичення радикалів у тканинах і пошкодження найчутливіших молекул протеїнів, ліпідів, ДНК. А це, у свою чергу, тягне за собою загибель клітин. У процесі старіння організму розвивається стан гіпоксії тканин, що індукує збільшення рівня відновлення компонентів дихального ланцюга та накопичення у тканинах субстратів, коферментів, флавін- і гемовмісних компонентів у відновленому стані. За цих умов надлишок донорів електронів може провокувати їх інтенсивніший витік, що пов'язано 3 додатковою генерацією активних форм оксигену, роз'єднанням окисного фосфорилювання, підвищенням лактату та, відповідно, розвитком стану ацидозу в тканинах. Таким чином, активація окисних процесів у мітохондріях кардіоміоцитів може викликати патогенез серцево-судинних захворювань (Marzetti et al., 2013; Zhao et al., 2014; Owada et al., 2017).

Продукти перекисного окиснення, які утворюються внаслідок збільшення концентрації активних форм оксигену, викликають глибокі зміни протеїнів, пов’язані з їх окисною деструкцією, зміною конформації (Tosi et al., 2014; Roya et al., 2017). Виходячи 3 цього, автори виявили у довгоживучих особин низький вміст ненасичених жирних кислот і низький рівень малонового діальдегіду - лізинових і карбоксиметил-лізинових протеїнових похідних у мітохондріях серця та печінки. Такий низький ступінь ненасиченості жирних кислот пов'язаний із генетично детермінованою низькою активністю $\mathrm{D}_{5}-\mathrm{i} \mathrm{D}_{6}$-десатураз (КФ 1.14.99.5) у довгоживучих особин. Показано зв'язок процесів старіння організму та окисної модифікації протеїнів у еритроцитах і фібробластах людини, гепатоцитах (Malathi and Rajamurugan, 2015). У старих еритроцитів збільшена концентрація карбонільних залишків окиснених протеїнів і знижена активність гліцеральдегід-3-фосфатдегідрогенази (КФ 1.2.1.12), аспартатамінотрансферази (КФ 2.6.1.1), фосфогліцераткінази (КФ 2.7.2.3). У фібробластах донорів відмічено зростання швидкості окиснених протеїнів залежно від віку. Така сама залежність виявлена під час дослідження гепатоцитів щурів різного віку.

Низка дослідників показали, що існує пряма залежність між умістом і активністю антиоксидантних ензимів у організмі та тривалістю життя (Anayt et al., 2017; Lykhatskyi and Fira, 2017). Пропонується гіпотеза, що, можливо, старіння пов'язане зі зниженням ензиматичної активності антиоксидантів. Особливо велика увага приділясться геропротекторній ролі супероксиддисмутази у процесі старіння організму (Das and Muniyappa, 2013). Виявлена позитивна кореляція між високим рівнем антиоксидантного захисту i, зокрема, супероксиддисмутази, і максимальною тривалістю життя. Однак, у той же час, існують абсолютно протилежні відомості, в яких зазначено, що ендогенні ензими-антиоксиданти та окремі низькомолекулярні антиоксиданти негативно корелюють із максимальною тривалістю життя.
Каталаза - один із найважливіших ензимів антиоксидантної системи, який вже при мінімальних кількостях перекису гідрогену проявляє свою активність і таким чином захищає клітину від розвитку окисного стресу (Marni et al., 2013; Serova et al., 2016; Dyomshina et al., 2017). Співавтори (Marques et al., 2015) розглядають каталазу разом із супероксиддисмутазою та непротеїновими тіолами цитоплазми як єдине окисно-відновне середовище клітини. У своїй праці автори стверджують, що активність каталази зменшується у щурів віком 24 місяці на тлі збільшення концентрації непротеїнових тіолів (головним чином представлених глутатіоном). У самців щурів, які регулярно піддавалися фізичному навантаженню, активність каталази у тканині міокарда збільшувалася. Це пояснюється тим, що під час фізичних навантажень відбулися адаптивні зміни в антиоксидантній системі організму, зокрема, зниження продукції активних форм оксигену (незважаючи на те, що потреба в оксигені та його потік до дихального ланцюга мітохондрій зросли), підвищення активності ензимів антиоксидантного захисту та окиснення ліпідів. У серцевому м'язі, печінці та скелетних м'язах тренованих тварин пошкодження клітин значно менші, ніж у тих, які вели малорухливий спосіб життя.

Один із механізмів природного старіння та загибелі клітини, що може спричинити передчасне старіння цілісного організму - підвищення концентрації цитохрому С у цитозолі, яке пов'язане з розвитком окисного стресу та свідчить про апоптичні процеси в клітинах. За підвищення концентрації перекисних продуктів у мітохондріях запускається механізм пероксидазної активності комплексу цитохрому $\mathrm{C}$ із кардіоліпіном (Demin, 2008; Birk et al., 2014). У результаті цього стимулюється дисоціація комплексу, внаслідок чого цитохром С вивільняється із зв'язку з кардіоліпіном. Активізується окиснення ліпідів, відбувається дезорганізація мітохондріальної мембрани, що підвищує іï проникність за рахунок або формування пор, або ініціації розкриття тимчасових пор перехідної проникності мембрани (Vickers, 2009; Begriche, 2011; Donghong, 2015; Boengler et al., 2017). Внаслідок цього відбувається вивільнення цитохрому С у цитоплазму, що запускає реакцію апоптозу клітини.

Існує ще один механізм підвищення проникності мітохондріальної мембрани внаслідок взаємодії протеїнів родини $\mathrm{Bcl} 2$ з тимчасовою порою перехідної проникності (Shan et al., 2015). У нормі така мітохондріальна пора замала для молекули цитохрому C, iii діаметр становить 2 нм. Але протеїни родини $\mathrm{Bcl} 2$ мають гідрофобні залишки, за допомогою яких здатні прикріплятися до зовнішньої мітохондріальної мембрани в області пори. Ці протеїни вступають у взаємодію з аденілатним транспортером, розширюючи канал пори до 3 нм. Саме через подібну пору відбувається вихід таких великих молекул як цитохром С. Скоріше за все, окисний стрес ініціює цей процес. Опинившись у цитоплазмі, цитохром С, за присутності АТР, взаємодіє з неактивними формами каспази-9 та APAF1, утворюючи апоптосому. Вже в апоптосомі відбувається активація каспази-9, яка стимулює каспазу-3 - головний фактор внутрішнього шляху апоптозу (Bonglee et al., 2015).

Далеко не останню роль у вивільненні цитохрому С відіграють активні форми оксигену, у першу чергу $\mathrm{O}_{2}^{--}$, які утворюються в дихальному ланцюзі перенесення електронів на рівні комплексу I (НАДН/убіхінон оксидоредуктази) та комплексу IV (цитохромоксидаза). Перетворення супероксиду мітохондріальною СОД викликає утворення ще однієї активної молекули оксигену $\mathrm{H}_{2} \mathrm{O}_{2}$, який у надмірній кількості може викликати пошкодження мітохондрій (Serova et al., 2016; Dyomshina et al., 2017; Owada et al., 2017). Слід зазначити, що за фізіологічного старіння підвищення чутливості до відкриття пори тимчасової

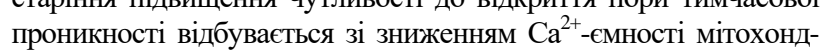
piй (Fernandez-Sanz et al., 2015; Rohit et al., 2016). Цьому можуть сприяти різні причини, зокрема, підвищення активності фосфоліпаз, а також збільшений вміст продуктів перекисного окиснення ліпідів у тканинах старих тварин. У міокарді старих щурів виникають умови для обмеження швидкості окисно-відновних 
перетворень у циклі трикарбонових кислот (Mdaki et al., 2016). Такі зміни швидкості найпотужнішого енергетично забезпечувального процесу свідчать про формування в мітохондріях так званої «напруги» в стані біоенергетичних процесів у серці. Це, у свою чергу, зумовлює появу з віком у тварин особливостей у зміні їх стану в умовах підвищення потреби серцевого м'яза в АТФ під час стресу (Tepp et al., 2016, 2017).

Ензим, який знаходиться на перетині вуглеводного, протеїнового та енергозабезпечувальних процесів, - лактатдегідрогеназа. Дослідження у серцевому м'язі щурів адаптаційних процесів за старіння та додаткових навантажень у вигляді фізичних вправ i різних температур показали зміни активності лактатдегідрогенази та iii ізоензимів (Prathima and Devi, 1999). Із віком у тварин за умов тренувань відбувався перерозподіл ізоферментів ЛДГ, що забезпечувало стійкість кардіоміоцитів до стресових впливів і поліпшення компенсаторних можливостей за зміни потреби в оксигені та зниження ризику розвитку кардіоваскулярних захворювань.

Незважаючи на численні дослідження причин старіння серця, участі мітохондрій у даному процесі, вирішення цього питання залишається актуальним донині. Тому мета цієї статті визначити зміни окремих біохімічних ланок функціонування мітохондрій серця піщанок за старіння.

\section{Матеріал і методи досліджень}

Експеримент проводили на монгольських піщанках (Meriones unguiculatus Milne-Edwards, 1867) різного віку із середньою вагою 63-83 г, яких утримували у стандартних умовах віварію. Маніпуляції з тваринами проводили відповідно до правил « $\mathrm{C}_{\mathrm{B}}$ ропейської конвенції із захисту хребетних тварин, які використовуються для експериментальних та інших наукових цілей» (Страсбург, 1986). Тварин поділили на п’ять дослідних груп (по 6 тварин у кожній): 1 - тварини віком 6 місяців, 2 -24 місяці, 3 30 місяців, 4 - 36 місяців, 5 - 39 місяців. Наприкінці тварин зважували та виводили з експерименту за етерного наркозу, видаляли серце, промивали у фізіологічному розчині та використовували для подальших досліджень.

Гомогенат серця, його водорозчинну та мітохондріальну фракції отримували шляхом диференційного центрифугування у градієнті сахарози методом Wieckowski et al. (2009). Визначення активності аспартатамінотрансферази (АсАТ, КФ 2.6.1.1), аланінамінотрансферази (АлАТ, КФ 2.6.1.2), лактатдегідрогенази (ЛДГ, КФ 1.1.1.27), $\gamma$-глутамінтрансферази (ГГТП, КФ 2.3.2.2) проводили 3 використанням стандартних лабораторних тест-наборів (Фелісіт, Дніпро) методами Burtis et al. (2012) та Young (2014) згідно з протоколом фірми виробника. Активність каталази (КТ, КФ 1.11.1.6) визначали за здатністю пероксиду гідрогену утворювати із солями молібдену стійкий забарвлений комплекс (Koroluk et al., 1988). Активність каталази виражали в мккат/мг протеїну мітохондріальної фракції. Активність супероксиддисмутази (СОД, КФ 1.15.1.1) оцінювали як здатність ензиму інгібувати реакцію окиснення кверцетину (Kostuk et al., 1990). Активність СОД виражали в умовних одиницях (у. о./мг протеїну). За умовну одиницю брали активність ензиму, який здатний викликати інгібування кверцетину на 50\% у розрахунку на протеїни тканини. Кількість ТБК-активних продуктів визначали за концентрацією забарвленого комплексу, який утворювався за реакції малонового діальдегіду (МДА) у кислому середовищі 3 двома молекулами тіобарбітурової кислоти (ТБК) (Andreeva et al., 1988). Кількість МДА виражали у мкмолях ТБКактивних продуктів на 1 мг протеїну мітохондріальної фракції. Кількість цитохрому C - за його здатністю відновлювати дітіонат натрію (Selivanov et al., 1997). Статистичний аналіз результатів проводили методом ANOVA. Вірогідними вважали відмінності за $\mathrm{P}<0,05$. Кореляційний аналіз проведено за коефіцієнтом Пірсона.

\section{Результати}

Аналіз стану прооксидантних чинників і антиоксидантної системи у водорозчинній фракції, отриманої з серця піщанок, показав збільшення концентрації ТБК-активних продуктів за досягнення тваринами віку 24 місяці (рис. 1).

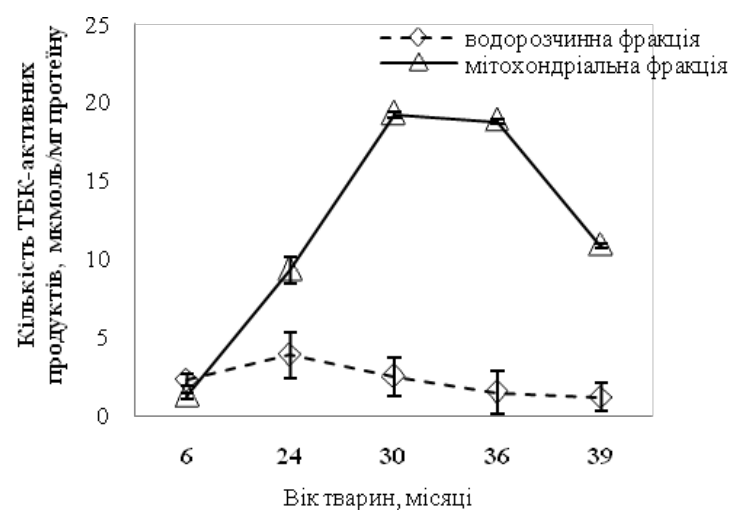

Рис. 1. Кількість ТБК-активних продуктів (прооксидантної системи) у водорозчинній та мітохондріальній фракціях, отриманих із серця піщанок різних вікових груп, мкмоль/мг протеїну $(\mathrm{x} \pm \mathrm{SD}, \mathrm{n}=6)$

Зі збільшенням віку зареєстровано поступове зменшення ТБК-активних продуктів, яке досягло $1,16 \pm 0,11$ мкмоль/мГ протеїну у піщанок віком 39 місяців порівняно з 6-місячними тваринами $(2,25 \pm 0,18$ мкмоль/мг протеїну). Таке явище пов'язане зі зниженням із віком концентрації ліпідів як основних субстратів ендогенної пероксидації та гальмуванням відновлення основних субстратів метаболізму - протеїнів і вуглеводів. У мітохондріальній фракції, отриманій із серця піщанок, визначено параболічне коливання концентрації ТБК-активних продуктів упродовж 24-39 місяців життя, що свідчить про розвиток суттєвого окисного стресу в дослідженому компартменті кардіоміоцитів, що супроводжує старіння.

Після 36 місяців життя у піщанок визначено зниження концентрації перекисних продуктів, що також пов'язано зі зниженням інтенсивності відновлення структурних компонентів мембран мітохондрій. Оскільки середня тривалість життя монгольських піщанок складає 24 місяці, і в цьому віці вже починаються процеси старіння, тварин віком 39 місяців можна вважати довгожителями. Аналізуючи співвідношення цитоплазматичного та мітохондріального рівня ТБК, варто зазначити, що у 6-місячних піщанок у водорозчинній фракції він трохи вищий, ніж у мітохондріальній. У старих тварин це співвідношення порушується. Починаючи 3 віку 24 місяці, рівень ТБК-активних продуктів у мітохондріях старих піщанок перевищує цитоплазматичний. Очевидно, що з віком у цитозолі зменшується кількість функціонально активних протеїнів і ліпідів, тому окисний стрес у цій фракції менш виражений, а отже, рівень перекисних продуктів нижчий. Зниження концентрації продуктів ТБК у піщанок віком 39 місяців, найстарших серед експериментальних тварин, відбувається, можливо, завдяки розвитку адаптивних процесів в антиоксидантній системі або зниженню загальнометаболічних процесів. Цілком зрозуміло, що у літньому віці процеси відновлення пошкоджень мітохондріальних мембран відбуваються менш ефективно.

Захист клітини від окисного стресу забезпечують ключові ензими: СОД, каталаза та протеїн цитохром С. Експериментальні дані (табл. 1, 2) вказують на незвичайне співвідношення активності супероксиддисмутази у водорозчинній та мітохондріальній фракціях, отриманих із серця дослідних піщанок.

У мітохондріальній фракції встановлено підвищення активності СОД у 3-6 разів серед груп старих тварин порівняно з 6-місячними, а у водорозчинній - навпаки, зменшення цієї активності. У мітохондріях і цитоплазмі клітин серця відбувалися хвилеподібні зміни активності СОД, пов'язані з віком піддослідних тварин. Відхилення активності СОД від першої групи (6 місяців) вперше відбувалося у віці 24 місяці. У період із 30 до 36 місяців визначено сплеск активності мітохондріальної СОД. Така динаміка зміни активності ензиму в цілому узгоджується зі зміною інших дослідних 
біохімічних показників у старіючих піщанок. Активність іншого ензиму антиоксидантної системи каталази зросла як у водорозчинній, так і в мітохондріальній фракціях серця піддослідних піщанок, відносно першої групи (6 місяців). Активність мітохондріаль- ного ізоензиму каталази значно вища, ніж цитозольного (табл. 1, 2). Динаміка зміни активності каталази у процесі старіння тварин також має хвилеподібний характер, причому найяскравіше простежується у водорозчинній фракції.

Таблиця 1

Активність ензимів антиоксидантної системи у водорозчинній фракції, отриманій із серця піщанок різних вікових груп $(\mathrm{x} \pm \mathrm{SD}, \mathrm{n}=6)$

\begin{tabular}{lcccc}
\hline \multirow{2}{*}{ Ензим } & \multicolumn{4}{c}{ Вік тварин, місяці } \\
\cline { 2 - 5 } \multicolumn{1}{c}{ СОД, у. о./мг протеїну } & $12,35 \pm 2,38$ & 24 & 30 & 36 \\
Каталаза, мккат/мг протеїну & $34,74 \pm 1,79$ & $9,38 \pm 2,28^{*}$ & $13,24 \pm 3,76$ & $5,15 \pm 0,22^{* *}$ \\
Цитохром С, нг/г тканини & $29,15 \pm 5,45$ & $90,47 \pm 13,21^{*}$ & $103,79 \pm 14,76^{*}$ & $90,56 \pm 8,22^{* *}$ \\
\hline
\end{tabular}

Примітка:* $-\mathrm{P}<0,05, * *-\mathrm{P}<0,01, * * *-\mathrm{P}<0,001$ відносно першої групи (6 місяців).

Таблиця 2

Активність ензимів антиоксидантної системи у мітохондріальній фракції, отриманій із серця піщанок різних вікових груп (x \pm SD, $\mathrm{n}=6$ )

\begin{tabular}{lcccc}
\hline \multirow{2}{*}{ Ензим } & \multicolumn{4}{c}{ Вік тварин, місяці } \\
\cline { 2 - 5 } \multicolumn{1}{c}{ СОД, у. о./мг протеїну } & $3,67 \pm 0,94$ & $12,13 \pm 2,12^{* *}$ & $23,40 \pm 4,05^{*}$ & 66 \\
Каталаза, мккат/мг протеїну & $2,13 \pm 0,64$ & $10,56 \pm 1,96^{*}$ & $9,74 \pm 1,63^{*}$ & $22,88 \pm 5,05^{*}$ \\
Цитохром С, нг/г тканини & $64,53 \pm 10,72$ & $33,39 \pm 14,76^{*}$ & $42,44 \pm 15,55^{*}$ & $10,39 \pm 1,1^{* *}$ \\
\hline
\end{tabular}

Примітка: див. табл. 1.

Одним із механізмів фізіологічного старіння та загибелі клітин, що може спричинити передчасне старіння цілого організму, розглядається підвищення концентрації цитохрому С у цитозолі, пов'язане з розвитком окисного стресу. У наших дослідах показано поступове підвищення концентрації цитохромму С у водорозчинній фракції, отриманій із серця, яке досягало максимального значення у найстаріших тварин (підвищення на 50\% порівняно із 6-місячними тваринами). У мітохондріальній фракції відбувалось зниження на 28-36\% залежно від вікової групи цього показника.
Відмічено статистичну різницю транспорту цитохрому С до мітохондрій міокарда у 24- та 36-місячних тварин. Цей факт вказує на існування двох переломних вікових періодів, у які мітохондрії найуразливіші до пошкоджувальної дії перекисних продуктів.

Важливі діагностичні параметри стану серця - активність ензимів лактатдегідрогенази, $\gamma$-глутамілтрансферази, амінотрансфераз, особливо аспартатамінотрансферази, зміни яких у водорозчинній фракції, отриманій із серця, подано у таблиці 3 , а мітохондріальних ізоензимів АлАт та АсАТ - у таблиці 4.

Таблиця 3

Активність ензимів водорозчинної фракції, отриманої із серця піщанок різних вікових груп (од./кг тканини, $\mathrm{x} \pm \mathrm{SD}, \mathrm{n}=6$ )

\begin{tabular}{|c|c|c|c|c|c|}
\hline \multirow{2}{*}{ Ензим } & \multicolumn{5}{|c|}{ Вік тварин, місяці } \\
\hline & 6 & 24 & 30 & 36 & 39 \\
\hline АлАТ & $7,13 \pm 0,79$ & $5,81 \pm 1,19 * *$ & $9,50 \pm 1,29 *$ & $7,39 \pm 0,91$ & $6,33 \pm 1,58$ \\
\hline AcAT & $8,87 \pm 1,44$ & $6,44 \pm 1,42^{* * *}$ & $7,92 \pm 0,91$ & $6,33 \pm 1,58$ & $5,28 \pm 1,83^{*}$ \\
\hline ГГТ & $2,81 \pm 0,54$ & $3,74 \pm 0,84$ & $4,68 \pm 0,54^{* * *}$ & $4,37 \pm 1,08 *$ & $4,30 \pm 0,54^{* * *}$ \\
\hline ЛДГ піруват & $37,99 \pm 9,59$ & $65,14 \pm 13,73^{*}$ & $84,49 \pm 11,50 * *$ & $68,18 \pm 2,01^{*}$ & $64,94 \pm 17,84^{*}$ \\
\hline ЛДГ лактат & $191,47 \pm 81,01$ & $69,44 \pm 13,55^{* *}$ & $88,49 \pm 20,85^{* *}$ & $45,02 \pm 10,43^{* * *}$ & $42,09 \pm 7,77^{* * *}$ \\
\hline
\end{tabular}

Примітка: див. табл. 1.

Таблиця 4

Активність мітохондріальних ізоформ амінотрансфераз серця піщанок різних вікових груп (од./кг тканини, $\mathrm{x} \pm \mathrm{SD}, \mathrm{n}=6$ )

\begin{tabular}{lcccc}
\hline & \multirow{2}{*}{ Ензим } & \multicolumn{3}{c}{ Вік тварин, місяці } \\
\cline { 2 - 5 } & 6 & 24 & 30 & 36 \\
\hline мАлАТ & $5,86 \pm 1,52$ & $11,19 \pm 1,77 *$ & $7,92 \pm 0,91$ & $6,97 \pm 0,32$ \\
мАсАТ & $18,37 \pm 1,44$ & $10,98 \pm 1,25 * * *$ & $16,15 \pm 1,31$ & $20,06 \pm 2,42 *$ \\
\hline
\end{tabular}

Примітка: див. табл. 1.

Активність аланінамінотрансферази (АлАТ) у водорозчинній фракції серця піщанок віком 24 місяці знижена на 20\% порівняно 3 першою групою (6 місяців). Із часом, по досягненні тваринами віку 30 місяців, зафіксовано підвищення активності цього ензиму порівняно 3 дворічними особинами на $40 \%$ та на $25 \%$ порівняно 3 6-місячними, після чого знову виявлено поступове зниження активності АлАТ. У мітохондріальній фракції, отриманій із серця піщанок, визначено іншу картину: за досягнення тваринами віку 24 місяці активність цієї трансамінази збільшувалася на 50\%, і надалі поступово знижувалась.

Для аспартатамінотрансферази (АсAТ) установлено іншу тенденцію змін активності. У водорозчинній фракції, отриманій із серця піщанок, активність ензиму знижувалася та у віці 39 місяців була нижчою за таку першої групи тварин (6 місяців) на 40\%. Активність мітохондріального ізоензиму в серці дворічних тварин знижувалася на $40 \%$ порівняно з першою групою. У тварин старшого віку відбувалось достовірне підвищення активності АсАТ порівняно з групою тварин віком 24 місяці, але вірогідно не відріз- нялася від дослідного показника у тварин віком 6 місяців. Активність мітохондріальних АлАт і АсАТ у серці піщанок суттєво відрізнялась від цитозольних ізоформ (табл. 4). У 24-місячних тварин активність мАлАТ збільшувалась порівняно з мАсАТ, активність якої, навпаки, зменшувалась. Отримані результати вказують на індукцію активності мАлАТ за рахунок збільшення у середовищі пірувату (табл. 3).

Ензим, який міститься на перетині анаеробного та аеробного енергозабезпечення клітини, - лактатдегідрогеназа. У тварин віком 24 місяці активність ЛДГ, спорідненої до лактату (ЛДГ лактат), знижується в 2,5 раза порівняно з першою групою тварин (6 місяців), потім дещо підвищується протягом 6 місяців, але лишається нижчою за першу групу та значимо зменшується у тварин старших 36 місяців (табл. 3). Варто звернути увагу на те, що у піщанок першої групи тварин (6 місяців), активність ЛДГ лактат вища, ніж ЛДГ, спорідненої до пірувату (ЛДГ піруват). У 24 місяці це співвідношення починає порушуватися, й у 30 місяців активність обох різновидів ензиму зрівнюється. У подальшому визначено зміну 
співвідношення у бік зростання активності ЛДГ піруват і зменшення ЛДГ лактат.

Один з ензимів, який бере участь у транспорті амінокислот до клітин, - $\gamma$-глутамілтранспептидаза (ГГТП). У нашому експери- менті у водорозчинній фракції, отриманій із серця піщанок, показано поступове підвищення активності цього ензиму (табл. 3). Проведено кореляційний аналіз дослідних параметрів за коефіцієнтом Пірсона (табл. 5, 6).

\section{Таблиця 5}

Кореляційні зв’язки між дослідними параметрами водорозчинної фракції, отриманої із серця піщанок $(\mathrm{x} \pm \mathrm{SD}, \mathrm{n}=6)$

\begin{tabular}{|c|c|c|c|c|c|}
\hline Кореляційний коефіцієнт Пірсона & 6 місяців & 24 місяці & 30 місяців & 36 місяців & 39 місяців \\
\hline ТБК-активні продукти - КТ & 0,60 & 0,61 & $0,95^{* * *}$ & $0,92^{* * *}$ & $-0,75^{*}$ \\
\hline ТБК-активні продукти - СОД & $-0,98 * * *$ & $-0,39$ & $-0,91 * * *$ & $0,84^{* *}$ & $-0,95 * * *$ \\
\hline ТБК-активні продукти - цитохром С & $-0,54$ & $0,82 * *$ & 0,02 & 0,03 & $-0,30$ \\
\hline СОД-цитохром С & $0,70^{*}$ & 0,09 & $-0,31$ & $-0,52$ & 0,58 \\
\hline СОД-КТ & $-0,56$ & $-0,46$ & $-0,75^{*}$ & $0,98 * * *$ & $0,92 * * *$ \\
\hline АлАТ - АсАТ & 0,58 & $-0,66$ & $-0,71^{*}$ & $0,87 * *$ & $0,87 * *$ \\
\hline АлАТ - ЛДГ лактат & $-0,73^{*}$ & 0,28 & $-0,87 * *$ & $-0,98 * * *$ & $-0,44$ \\
\hline АлАТ - ЛДГ піруват & 0,51 & 0,66 & $-0,58$ & 0,10 & $0,92 * * *$ \\
\hline ЛДГ лактат - ЛДГ піруват & $-0,47$ & 0,35 & 0,62 & $-0,99 * * *$ & $-0,05$ \\
\hline ГГТП - цитохром С & $0,78^{*}$ & $-0,12$ & $-0,51$ & $-0,80 * *$ & $0,99 * * *$ \\
\hline АлАТ - ГГТП & $-0,23$ & 0,26 & 0,12 & $-0,55$ & $0,82^{* *}$ \\
\hline AcAT - ГГТП & $-1,00 * * *$ & $1,00 * * *$ & 0,01 & 0,01 & 0,01 \\
\hline
\end{tabular}

Примітка: див. табл. 1.

У водорозчинній фракції, отриманій із серця піщанок, установлено прямий зв'язок високого ступеня значимості між кількістю ТБК-активних продуктів і активністю каталази $(\mathrm{r}=0,95, \mathrm{P}<$ $0,001)$ у віці 30 місяців, $(\mathrm{r}=0,92, \mathrm{P}<0,001)$ у віці 36 місяців, тоді як у віці 6 місяців спостерігався поміркований прямий зв'язок (r = $0,60, \mathrm{P}<0,05)$ та $(\mathrm{r}=0,61, \mathrm{P}<0,05)$ у віці 24 місяці. У тварин похилого віку (понад два роки) визначено позитивну залежність між активністю СОД і каталази ( $\mathrm{r}=0,98, \mathrm{P}<0,001 ; \mathrm{r}=0,92, \mathrm{P}<$ 0,001), кількістю ТБК-активних продуктів і активністю СОД (r = 0,84, P < 0,01); кількістю ТБК-активних продуктів та вмістом цитохрому C ( $\mathrm{r}=0,82, \mathrm{P}<0,01)$; активністю СОД і кількістю цитохрому $\mathrm{C}(\mathrm{r}=0,70, \mathrm{P}<0,05)$. Таким чином, із віком збільшення концентрації прооксидантних чинників викликає активізацію високомолекулярних компонентів системи антиоксидантного захисту у цитозолі кардіоміоцитів. Активізація прооксидантної системи опосередковано ініціює процес загибелі клітин шляхом підвищення концентрації цитохрому С у цитозолі.

Аналіз кореляційних зв’язків між дослідженими біохімічними маркерами стану міокарда піщанок похилого віку показав наявність прямого зв’язку високого ступеня значимості між активністю аланінамінотрансферази та лактатдегідрогенази, субстрат якої - піруват ( $\mathrm{r}=0,92, \mathrm{P}<0,001)$; активністю аланінамінотрансферази та аспартатамінотрансферази ( $\mathrm{r}=0,87$, $\mathrm{P}<0,01)$; активністю ГГТП та кількістю цитохрому С $(\mathrm{r}=0,99$, $\mathrm{P}<0,001)$; активністю аланінамінотрансферази та ГГТП $(\mathrm{r}=0,82$, $\mathrm{P}<0,01)$. Тобто $з$ віком активність одних ензимів викликає підвищення концентрації субстратів для інших ензимів основних метаболічних шляхів у клітині, що старіє.

Установлено відмінний зв’язок високого ступеня значимості між кількістю ТБК-активних продуктів як основного компонента прооксидантної системи та активністю СОД як високомолекулярного ензиму антиоксидантної системи, $\mathrm{r}=-0,98$, $\mathrm{P}<0,001$ у водорозчинній фракції міокарда тварин віком 6 місяців, $\mathrm{r}=-0,91, \mathrm{P}<0,001-30$ місяців і $\mathrm{r}=-0,95, \mathrm{P}<0,001$ 39 місяців. Отже, інтенсифікація утворення перекисних продуктів викликає інгібування активності СОД. Кореляційний аналіз підтверджує літературні дані про те, що надмірні концентрації перекису інгібують СОД. Кореляційний аналіз між активністю основних високомолекулярних компонентів антиоксидантної системи СОД і каталазою показав також зростання відмінного зв'язку високого ступеня значимості з віком: $\mathrm{r}=$ $-0,75, \mathrm{P}<0,05$ у тварин віком 24 місяці; $\mathrm{r}=-0,87, \mathrm{P}<0,01-$ 30 місяців і r $=-0,98, \mathrm{P}<0,001-36$ місяців.

Активність лактатдегідрогенази, субстрат якої - піруват, мала відмінний зв’язок високого ступеня значимості 3 активністю лактатдегідрогенази, субстрат якої - лактат $\mathrm{r}=-0,99, \mathrm{P}<0,001$ у тварин похилого віку. Отримані дані вказують на превалювання анаеробного шляху перетворення глюкози у серцевому м'язі з віком.

Між активністю аспартатамінотрансферази та $\gamma$-глутамілтранспептидази у водорозчинній фракції серця визначено обернено пропорційну залежність у 6-місячних піщанок ( $=-1,00)$, яка з віком (24 місяці) змінювалась на позитивну $(\mathrm{r}=1,00)$, i зі збільшенням віку втрачалась будь-яка залежність між активностями вказаних ензимів.

У мітохондріальній фракції серця піщанок установлено прямий зв’язок високого ступеня значимості між кількістю прооксидантних ТБК-активних продуктів і активністю антиоксидантного ензиму СОД ( $\mathrm{r}=0,86, \mathrm{P}<0,001)$ у тварин віком 30 місяців, $\mathrm{r}=0,95, \mathrm{P}<0,001$ у тварин віком 39 місяців (табл. 6).

\section{Таблиця 6}

Кореляційні зв’язки між дослідними параметрами мітохондріальної фракції, отриманої із серця піщанок $(\mathrm{x} \pm \mathrm{SD}, \mathrm{n}=6)$

\begin{tabular}{lcccc}
\hline Кореляційний коефіцієнт Пірсона & 6 місяців & 24 місяці & 30 місяців & 36 місяців \\
\hline ТБК-активні продукти - КТ & $-0,91 \pm 0,83^{* * *}$ & $0,21 \pm 1,95$ & $-0,36 \pm 1,86$ & $0,01 \pm 2,00$ \\
ТБК-активні продукти - СОД & $-0,04 \pm 1,99$ & $0,34 \pm 1,88$ & $0,86 \pm 0,99 * *$ & $0,63 \pm 1,56$ \\
ТБК-активні продукти - цитохром С & $0,89 \pm 0,90^{* * *}$ & $0,56 \pm 1,65$ & $0,39 \pm 1,84$ & $0,27 \pm 1,92$ \\
СОД-цитохром С & $-0,15 \pm 1,97$ & $-0,20 \pm 1,96$ & $0,60 \pm 1,60$ & $0,95 \pm 0,65 * * *$ \\
СОД-КТ & $-0,28 \pm 1,92$ & $-0,22 \pm 1,95$ & $-0,23 \pm 1,94$ & $0,01 \pm 0,77 * * *$ \\
АлАТ - АсАТ & $0,61 \pm 1,58$ & $0,12 \pm 1,98$ & $0,70 \pm 1,43^{*}$ & $0,03 \pm 1,99$
\end{tabular}

Примітка: див. табл. 1.

На відміну від цитозолю, у мітохондріях із віком відбувається посилення кореляційного зв'язку між даними показниками. Це може вказувати на те, що з віком саме мітохондріальний ізоензим СОД стає джерелом утворення перекису. Також установлено прямий зв'язок високого ступеня значимості між кількістю ТБК-активних продуктів та вмістом цитохрому С $(\mathrm{r}=0,89, \mathrm{P}<0,001)$ у піщанок віком 6 місяців. Із віком кореля- ційний зв’язок слабшав, однак у тварин віком 39 місяців посилювався та змінювався на від'ємний $(\mathrm{r}=-0,73, \mathrm{P}<0,05)$. Отже, у похилому віці в мітохондріях підвищена концентрація перекису може провокувати зниження концентрації цитохрому C. Кореляційний аналіз інших показників у мітохондріальній фракції, отриманій із серця піщанок, показав наявність помірних зв’язків. 


\section{Обговорення}

3'ясування співвідношення прооксидантних чинників i стану антиоксидантної системи у водорозчинній фракції серця піщанок показало збільшення концентрації ТБК-активних продуктів у 24-місячному віці (табл. 1). У подальшому відбувається поступове зменшення цього показника (мінімум - у віці 39 місяців). Таке явище, перш за все, пов'язане зі зниженням концентрації ліпідів як основних субстратів ендогенної пероксидації. Із віком відбувається гальмування відновлення основних субстратів метаболізму - протеїнів, вуглеводів, ліпідів, найчутливіших до дії будь-яких несприятливих факторів.

У мітохондріальній фракції, отриманій із серця піщанок, спостерігали різке підвищення концентрації ТБК-активних продуктів (у 9-19 разів порівняно з першою групою тварин віком 6 місяців). Це свідчить про суттєвий окисний стрес, що супроводжує старіння (табл. 2). Після 36 місяців життя відбувається зниження концентрації перекисних продуктів, що також пов'язано зі зниженням інтенсивності відновлення структурних компонентів мембран мітохондрій. Оскільки середня тривалість життя монгольських піщанок складає 24 місяці, у цьому віці вже посилюються процеси старіння, і тварин віком 39 місяців можна вважати довгожителями. 3 огляду на це, встановлений рівень ТБК-активних продуктів означає, що процеси ПОЛ і руйнування протеїнів клітинних мембран уже відбулися, і система антиоксидантного захисту намагається пристосуватися до таких навантажень для забезпечення енантіостазу. Це підтверджується літературними даними (Judge and Leeuwenburgh, 2007; Marques et al., 2015; Anayt et al., 2017).

Аналізуючи співвідношення цитоплазматичного та мітохондріального рівня ТБК, слід зазначити, що у 6-місячних піщанок у водорозчинній фракції він вищий, ніж у мітохондріальній. У групах старих тварин таке співвідношення порушується. Починаючи з віку 24 місяці, рівень ТБК-активних продуктів у мітохондріях старих піщанок перевищує цитоплазматичний. Очевидно, з віком у цитозолі зменшується кількість функціонально активних протеїнів і ліпідів, тому окисний стрес у цій фракції менше виражений, а отже, рівень перекисних продуктів нижчий. За час атаки активними формами оксигену, головним чином, пошкоджуються біомембрани органел $і$ самої клітини. Оскільки мітохондрії вважаються осередком утворення активних форм оксигену, процеси перекисного окиснення та окисної модифікації протеїнів більше виражені, а отже, рівень ТБК-активних продуктів вищий. Тобто у старіючих тварин окисне пошкодження найбільше виявляється в мітохондріях. Надлишкове утворення перекисних продуктів викликає накопичення дисфункціональних і аномальних мітохондрій, що визначається важливою патофізіологічною особливістю старіння серця (Ikeda et al., 2014; Zhao et al., 2014). У похилому віці знижується ефективність репараційних процесів, а саме аутофагія / мітофагія, тобто видалення пошкоджених, не функціональних мітохондрій (Hayat, 2014; Lekli et al., 2017).

Зниження концентрації ТБК-активних продуктів у піщанок віком 39 місяців, найстарших серед експериментальних тварин, відбувається завдяки розвитку адаптаційних процесів у антиоксидантній системі. Беручи до уваги недостовірне зниження перекисних продуктів у водорозчинній фракції, можна припустити, що, крім високомолекулярних сполук антиоксидантного захисту, до цього процесу також залучаються низькомолекулярні антиоксиданти, наявні в дуже низьких концентраціях у цитоплазмі клітини.

У літньому віці процеси відновлення пошкоджень клітин відбуваються менш ефективно (Zhao et al., 2014; Owada et al., 2017; Teppa et al., 2017). Ресурси старого організму обмежені, тому повністю відновити всі пошкодження через компенсаторні реакції йому вже не вдається. Внаслідок цього починають розвиватися патологічні процеси. У цьому випадку пошкоджені клітини міокарда вже повністю не відновлюються, а в деяких місцях будуть спостерігатися ділянки, заміщені сполучною тканиною (Anmann et al., 2014; Ikeda et al., 2014). Отже, пошкодження серцевого м’яза у піщанок мають місце після 24 місяців життя.

У водорозчинній та мітохондріальній фракціях, отриманих із серця піщанок дослідних груп, спостерігається таке співвідношення активності супероксиддисмутази. У мітохондріальній фракції вона підвищується в 3-6 разів в усіх дослідних груп, а у водорозчинній - зменшується порівняно 3 першою групою тварин (6 місяців). У мітохондріях і цитоплазмі (табл. 1, 2) відбувалися хвилеподібні зміни активності СОД. Вони пов'язані 3 віком дослідних тварин. Відхилення активності супероксиддисмутази від значень шестимісячних піщанок вперше відбувається у віці 24 місяці. У період 30-36 місяців відбувається сплеск активності мітохондріальної СОД. У водорозчинній фракції, отриманій із серця 24-місячних тварин активність супероксиддисмутази дещо знижується, у 30 місяців повертається до показників 6-місячних тварин, у 36 місяців активність значно зменшується, а в 39 місяців (найстаріші тварини) - знову повертається до рівня 6-місячних тварин. Така динаміка зміни активності ензиму, в цілому, узгоджується зі зміною інших досліджуваних показників у старіючих піщанок.

Одразу декілька авторів вказують, що активність СОД цитоплазми та мітохондрій обернено пропорційна тривалості життя (Das and Muniyappa, 2013; Anayt et al., 2017; Lykhatskyi and Fira, 2017). Тобто, у довгоживучих організмів ії̈ активність не змінюється, або зміни незначні. Більшість авторів стверджують, що у старіючих організмах відбувається пригнічення функціонування супероксиддисмутази та системи антиоксидантного захисту в цілому. Однак, вищезгадані дослідження проведені на лабораторних щурах віком 24 місяці. У нашому експерименті дослідні піщанки досягали віку 39 місяців. Літературні дані, де б фігурували настільки старі тварини, відсутні.

Беручи до уваги літературні та отримані під час нашого експерименту дані, у тварин-довгожителів підвищення активності мітохондріальної СОД і повернення активності цитоплазматичної СОД до рівня 6-місячних можна пояснити ефектом пристосування клітин до зниженої інтенсивності метаболізму. Із віком рівень продукції активних форм оксигену та завданих ними пошкоджень клітин збільшується, тому відбувається пристосування систем захисту для нейтралізації пошкодження біологічних молекул і захисту клітин від загибелі. Однак енергетичні ресурси старого організму обмежені, тому певний окисний стрес і пошкодження клітин міокарда все ж відбуваються. Це припущення підтверджують підвищені рівні ТБК-активних продуктів і активності лактатдегідрогенази, спорідненої до пірувату (табл. 3,4 ).

Активність каталази, одного 3 ензимів антиоксидантного захисту, зростала як у водорозчинній, так і в мітохондріальній фракціях піддослідних піщанок відносно першої групи тварин (6 місяців). При цьому в мітохондріях вона була більшою (табл. 1, 2). Зміна активності каталази також мала хвилеподібний характер. Каталаза стійка до зовнішніх впливів і першою вступає в реакцію знешкодження перекису. Ї̈̈ активність залежить від концентрації ТБК-активних продуктів.

У водорозчинній фракції серця після 24 місяців життя концентрація ТБК-активних продуктів підвищувалася, а потім поступово зменшувалася, одночасно із цим активність каталази підвищувалася утричі та залишалася на такому рівні до кінця дослідного терміну життя тварин. Збільшення вмісту ТБК-активних продуктів корелювало з активацією каталази в усіх вікових групах понад 24 місяці. 3 віком у піщанок поступово зростає продукція активних форм оксигену, які пошкоджують біологічні молекули. При цьому руйнівний вплив спрямований переважно на мітохондрії, тому починає активізуватися каталаза. Її активність у мітохондріальній фракції серця старих тварин порівняно з 6-місячними вища уп'ятеро. Але у найстарших тварин (39 місяців) інтенсивність перекисного окиснення стає нижчою, а активність каталази як у цитоплазмі, так і в мітохондріях залишається вищою за значення першої групи тварин (6 місяців). Особливо важливий цей ензим має саме у міто- 
хондріях, де деструктивні процеси з віком набувають критичного значення. Пероксид гідрогену пошкоджує ліпіди та білки мембран клітин і органел, що спричиняє накопичення продуктів ТБК. На це організм відповідає збільшенням активності каталази. Руйнівний вплив зачіпає також мітохондрії. Щоб зберегти гомеостаз і життя, організм починає пристосовуватися до нових умов існування шляхом запуску адаптивних реакцій. Одна з таких реакцій - висока активність каталази у цитозолі та мітохондріях, яка захищає клітину від смертельних пошкоджень. Таким чином, із віком саме каталаза виконує основну роль в адаптації клітин до підвищеної інтенсивності катаболічних, деструктивних, протеолітичних процесів.

Одним із механізмів природного старіння та загибелі клітини, що може спричинити передчасне старіння цілого організму, вважають підвищення концентрації цитохрому С у цитозолі, пов’язане 3 розвитком окисного стресу. Підвищення концентрації перекисних продуктів у мітохондріях запускає механізм пероксидазної активності комплексу цитохрому C iз кардіоліпіном (Demin, 2008; Birk et al., 2014). У результаті цього стимулюється дисоціація комплексу, внаслідок чого цитохром С відщеплюється від кардіоліпіну. Активізується окиснення ліпідів, відбувається дезорганізація мітохондріальної мембрани, що підвищує їі проникність за рахунок або формування пор, або ініціації розкриття тимчасових пор проникності мембрани (Vickers, 2009; Begriche, 2011; Donghong, 2015). Відбувається вивільнення цитохрому С у цитоплазму, що запускає реакцію апоптозу клітини. У наших дослідах показано поступове підвищення вмісту цитохрому С у водорозчинній фракції серця, яке досягало максимального значення у найстаріших тварин (підвищення на 50\% порівняно із 6-місячними тваринами). Одночасно у мітохондріальній фракції відбувається зниження 3 піком 36\% у двох вікових груп - 24 та 36 місяців. Цей факт вказує на існування двох переламних вікових періодів, у які мітохондрії найчутливіші до пошкоджувальної дії перекисних продуктів.

Наявність цитохрому $\mathrm{C}$ у цитоплазмі може провокувати апоптичні процеси у клітинах міокарда старих піщанок. Існує ще один механізм підвищення проникності мітохондріальної мембрани внаслідок взаємодії протеїнів родини Bcl 2 тимчасовою порою перехідної проникності (Shan et al., 2015). У нормі така мітохондріальна пора замала для молекули цитохрому C, iї діаметр становить 2 нм. Але протеїни родини $\mathrm{Bcl} 2$ мають гідрофобні залишки, здатні прикріплятися за їх допомогою до зовнішньої мітохондріальної мембрани в області пори, вступають у взаємодію з аденілатним транспортером, розширюючи канал пори до 3 нм. Саме через подібні пори відбувається вихід таких великих молекул, як цитохром С. Скоріше за все, окисний стрес, що формується у серці старіючих піщанок, також ініціює цей процес.

Результати розподілу цитохрому С у цитозолі та мітохондріях підтверджують літературні дані про те, що активні форми оксигену здатні індукувати апоптоз, та про роль цитохрому C як апоптичного фактора. Його поступове збільшення у мітохондріальній фракції у віці 30 та 39 місяців - додаткове підтвердження того, що в організмі піщанок-довгожителів вмикаються адаптаційні механізми: пристосування мітохондрій до метаболічного навантаження. Можливо, саме лабільністю та «живучістю» мітохондрій зумовлений феномен довголіття.

Важливі діагностичні параметри стану серця - активність ензимів лактатдегідрогенази, $\gamma$-глутамілтрансферази, амінотрансфераз, особливо аспартатамінотрансферази, зміни яких у водорозчинній та мітохондріальній фракціях наведено у таблицях 3 та 4. Активність АлАТ у водорозчинній фракції, отриманій із серця піщанок, у дворічних тварин знижується на $20 \%$ порівняно з 6-місячними. Із часом, по досягненні віку 30 місяців, зафіксовано підвищення активності цього ензиму порівняно 3 24-місячними особинами на 40\% та 6-місячними - на $25 \%$. У подальшому відбувалось поступове зниження активності АлАТ. У мітохондріальній фракції серця спостерігали інакшу картину. Для АсАТ спостерігали іншу тенденцію: саме у віці 24 місяці відбувається зниження активності обох трансаміназ у водорозчинній фракції, що пояснюється, насамперед, протеолітичними процесами, які підтверджено даними щодо зниження загальної кількості протеїну в досліджених фракціях. Про адаптаційні процеси, які відбуваються у подальшому, свідчить збільшення активності цих ензимів.

У мітохондріях спостерігали суттєво іншу картину: перенаправлення метаболічних процесів. У віці 24 місяці активність мітохондріального ізоензиму АлАТ збільшувалась порівняно $з$ АсАТ, активність якої, навпаки, зменшувалась, що вказує на підвищення концентрації пірувату. Це підтверджено даними щодо активності ЛДГ піруват. Цей факт підтверджено прямим кореляційним зв'язком високого ступеня значимості $(\mathrm{r}=0,92, \mathrm{P}<0,001)$ між активністю аланінамінотрансферази та ЛДГ піруват У водорозчинній фракції, отриманій із серця найстаріших піщанок віком 39 місяців (табл. 5). У цьому випадку незвичний той факт, що в нормі активність мітохондріального ізоензиму АлАТ низька, а його підвищення в мітохондріях серця тварин похилого віку вказує на збільшення концентрації недоокиснених продуктів, а саме пірувату. Переробляти піруват у надлишкових кількостях за старіння мітохондрії серця не здатні. Тому одним зі шляхів його перетворення стає утворення або аланіну, або лактату. Також на нездатність мітохондрій перетворювати піруват вказує одночасне зниження активності AcАТ, яка у мітохондріях забезпечує цикл трикарбонових кислот оксалоацетатом. Отже, отримані дані свідчать не тільки про перенаправлення метаболічних процесів, а і про порушення енергетичних процесів у клітинах міокарда під час старіння. АсАТ також бере участь у роботі малат-аспартатного човникового механізму та забезпечує цитоплазму субстратами для глюконеогенезу (перетворення пірувату на глюкозу) та синтезу протеїнів. Зниження активності AcАТ у мітохондріальній фракції свідчить про пригнічення цих процесів під час старіння. Із віком відбувається відносне відновлення активності амінотрансфераз, що вказує на адаптацію мітохондрій щодо забезпечення енергією серцевого м'яза за старіння організму.

Ензим, який знаходиться на перетині вуглеводного, протеїнового та енергозабезпечувальних процесів, - лактатдегідрогеназа. Варто звернути увагу на те, що у піщанок віком 6 місяців активність ЛДГ, спорідненої до лактату, вища, ніж ЛДГ, спорідненої до пірувату (табл. 3). Цей факт підтверджено літературними даними (Prathima and Devi, 1999), що кардіоміоцити активно перетворюють лактат на піруват із подальшим утворенням глюкози. У 24 місяці це співвідношення починає порушуватися, а у 30 місяців активність обох ізоформ ензиму зрівнюється. У подальшому відбувається зміна співвідношення у бік зростання ЛДГ піруват і зменшення ЛДГ лактат. За старіння міокарда процес перетворення пірувату на лактат превалює, що блокує залучення пірувату до ЦТК і глюконеогенезу. На цей факт також вказує зниження активності АсАТ у старих особин. Тобто в клітинах серця старіючих піщанок відбувається інтенсифікація анаеробних процесів, які дають менше енергіï, ніж дихальний ланцюг мітохондрій. Із віком відбуваються незворотні ушкодження кардіоміоцитів, які поступово втрачають здатність перетворювати лактат, внаслідок чого його кількість зростає, а утилізація інгібується.

Один з ензимів, які беруть участь у транспорті амінокислот до клітин - $\gamma$-глутамілтранспептидаза (ГГТП). В нашому експерименті у водорозчинній фракції серця піщанок відмічали поступове підвищення активності цього ензиму (табл. 3). Літературні дані (Whitfield, 2001; Babiy et al., 2010) вказують, що збільшення активності ензиму відображає динаміку відновних процесів у клітинах і розцінюється як загальна відповідь організму на патологічний стан, що розвивається.

Аналіз результатів показав, що для піщанок переломний вік - 24 місяці. Скоріше за все, в цьому віці відбуваються зміни напрямків метаболічних процесів: превалювання катаболічних над анаболічними процесами. Із віком у саркоплазмі кардіоміоцитів і ендотеліоцитів спостерігається включення ліпідів i ліпофусцину, зниження кількості рибосом, полісом і гранул 
глікогену (Rudnyova et al., 2014). Більше того, під час старіння клітин виявляються зміни ультраструктури мітохондрій: частина з них сильно набряклі з просвітленим матриксом і розширеними просторами між кристами, інша перебуває на різних стадіях дегенерації, що супроводжується лізисом крист і зовнішніх мембран. Дегенеративні та деструктивні зміни мітохондрій свідчать про істотне порушення внутрішньоклітинної біоенергетики.

В організмі старіючих піщанок спостерігається перерозподіл метаболітів і активізація адаптивних процесів, завдяки чому зберігається життєдіяльність цілісного організму, але на новому метаболічному рівні. Також можлива реалізація ще одного шляху адаптації кардіоміоцитів частково за рахунок видалення пошкоджених мітохондрій за механізмом аутофагії або мітофагії, які контролюють якість мітохондрій і гомеостаз серця (Hayat, 2014; Biala et al., 2015; Lekli et al., 2017), що потребує подальших досліджень.

\section{Висновки}

У старіючих тварин відбуваються порушення метаболічних процесів у міокарді. Підвищується рівень генерації активних форм оксигену, що пошкоджують біологічні молекули, руйнівний вплив яких спрямований переважно на мітохондрії, що, в цілому, спричиняє погіршення енергопостачання клітин. Із віком збільшується частка анаеробного дихання, внаслідок накопичення лактату. Загалом відбувається пошкодження та загибель клітин серця, вивільнення цитохрому С у цитоплазму, превалювання протеолітичних процесів, зниження загальної концентрації протеїну, перерозподіл метаболітів. Одночасно відбувається активізація адаптаційних процесів, спрямованих на збереження енантіостазу та життєдіяльності цілісного організму, але на новому метаболічному рівні. Доведено, що мітохондрії відіграють важливу роль у процеcax, залучених до старіння серця, та адаптаційних процесах кардіоміцитів. Можливо, саме лабільністю та «живучістю» мітохондрій зумовлений феномен довголіття.

\section{References}

Anayt, U., Mustafe, K. M., \& Biswajit, S. (2017). Coenzyme $Q_{10}$ prevents oxidative stressand fibrosis in isoprenaline induced cardiacremodeling in aged rats. BMC Pharmacology and Toxicology, 18(1), 1-10.

Andreeva, L. Y., Kozhemjakyn, L. A., \& Kyshkun, A. A. (1988). Modyfykacyja metoda opredelenyja perekysej lypydov v teste s tyobarbyturovoj kyslotoj [Modification of the method for the determination of lipid peroxides in the test with thiobarbituric acid]. Laboratory Work, 2, 41-43 (in Russian).

Anmann, T., Varikmaa, M., Timohhina, N., Tepp, K., Shevchuk, I., Chekulayev, V., Saks, V., \& Kaambre, T. (2014). Formation of highly organized intracellular structure and energy metabolism in cardiac muscle cells during postnatal development of rat heart. Biochemistry Biophysics Acta, 1837(8), 1350-1361.

Babij, S. O., Domshyna, O. O., \& Shtemenko, N. I. (2010). $\gamma$-Glutamiltransferaza $\mathrm{v}$ modeli kancerogenezu u shhuriv $[\gamma$-Glutamyltransferase in the model of carcinogenesis in rats]. Visnyk of Dnipropetrovsk University. Biology, Medicine, 1(1), 28-33 (in Ukrainian).

Begriche, K., Massart, J., Robin, M.-A., Borgne-Sanchez, A., \& Fromenty, B. (2011). Drug-induced toxicity on mitochondria and lipid metabolism: Mechanistic diversity and deleterious consequences for the liver. Journal of Hepatology, 54, 773-794.

Biala, A. K., Dhingra, R., \& Kirshenbaum, L. A. (2015) Mitochondrial dynamics: Rchestrating the journey to advanced age. Journal of Molecular and Cellular Cardiology, 83, 37-43.

Birk, A. V., Chao, W. M., Bracken, C., Warren, J. D., \& Szeto, H. H. (2014). Targeting mitochondrial cardiolipin and the cytochrome c/cardiolipin complex to promote electron transport and optimize mitochondrial ATP synthesis. British Journal of Pharmacology, 171(8), 2017-2028.

Bonglee, K., Sanjay, K. S., \& Sung-Hoon, K. (2015). Caspase-9 as a therapeutic target for treating cancer. Expert Opinion on Therapeutic Targets, 19(1), 113-127.

Burtis, C., Ashvud, E., \& Bruns, D. (2012). Textbook of clinical chemistry and molecular diagnostics. WB Saunders, Filadelfiya.

Das, K. C., \& Muniyappa, H. (2013) Age-dependent mitochondrial energy dynamics in the mice heart: Role of superoxide dismutase-2. Experimental Gerontology, 48(9), 947-959.
Demin, E. M., Proskurnina, E. V., \& Vladimirov, Y. (2008). Antioxidant effect of DHQ and rutin in peroxidase reactions catalyzed by cytochrom C. Moscow University Bulleten Chemistry 49(3), 354-360.

Donghong, L., \& Lei, L. (2015). Apoptosis of hela cells induced by a newtargeting photosensitizer-based PDT via a mitochondrial pathway and ER stress. OncoTargets and Therapy, 7(8), 703-711.

Dyomshina, O. O., Ushakova, G. O., \& Stepchenko, L. M. (2017). The effect of biologically active feed additives of humilid substances on the antioxidant system in liver mitochondria of gerbils. Regulatory Mechanisms in Biosystems, 8(2), 185-190 (in Ukrainian).

Fernandez-Sanz, C., Ruiz-Meana, M., \& Castellano, J. (2015). Altered FoF1 ATP synthase and susceptibility to mitochondrial permeability transition pore during ischaemia and reperfusion in aging cardiomyocytes. Thrombosis and Haemostasis, 113(3), 441-451.

Hayat, E. (2014). Cardiac senescence and autophagy. Tumor Dormancy, Quiescence, and Senescence: Aging, Cancer, and Noncancer Pathologies, 3, 125-137.

Ikeda, Y., Sciarretta, S., \& Nagarajan, N. (2014). New insights into the role of mitochondrial dynamics and autophagy during oxidative stress and aging in the heart. Oxidative Medicine and Cellular Longevity, ID 210934.

Judge, S., \& Leeuwenburgh, C. (2007). Cardiac mitochondrial bioenergetics, Oxidative stress and aging. American Journal of Physiology. Cell Physiology, 292(6), 1983-1992.

Koroljuk, M. A., Yvanova, L. Y., Majorova, Y. G., \& Tokareva, V. E. (1988). Metod opredelenyja aktyvnosty katalazy [Method for the determination of catalase activity]. Laboratory Work, 1, 16-19 (in Russian).

Kostjuk, V. A., Potapovych, A. Y., \& Kovaleva, Z. V. (1990). Prostoj i chuvstvitel'nyj metod opredelenija aktivnosti superoksiddismutazy, osnovannyj na reakcii okislenija kvercetina [A simple and sensitive method for determining the activity of superoxide dismutase, based on the oxidation reaction of quercetin]. Questions of Medical Chemistry, 36(2), 88-91 (in Russian).

Lakatta, E. G. (2015). So! What's aging? Is cardiovascular aging a disease? Journal of Molecular Cellular Cardiology, 83, 1-13.

Lekli, I., Haines, D. D., Balla, G., \& Tosaki, A. (2017). Autophagy: An adaptive physiological countermeasure to cellular senescence and ischaemia / reperfusion-associated cardiac arrhythmias. Joumal of Cellular and Molecular Medicine, 21(6), 1058-1072.

Lopez-Otin, C., Blasco, M. A., Partridge, L., Serrano, M., \& Kroemer, G. (2013). The hallmarks of aging. Cell, 153(6), 1194-1217.

Lykhatskyi, P. H., \& Fira, L. S. (2017). Activity of oxidative processes in the rats' body of different age, affected by sodium nitrite, on the background of tobacco intoxication. The Pharma Innovation Journal, 6(6), 18-24.

MacQueen, H. A., Wassif, W. S., \& Walker, I. (2011). Age-related biomarkers can be modulated by diet in the rat. Food and Nutrition Sciences, 2, 884-890.

Malathi, R., \& Rajamurugan, R. (2015). Protection against oxidative damage using momordica charantia extract incase of phenyl hydrazine induced hemolysis. Intemational Journal of Recent Scientific Research, 6(7), 5209-5214.

Marni, E. C., Muneaki, T., Kenichi, I., \& Kuniyasu, O. (2013). Orally supplemented catechin increases heme amounts and catalase activities in rat heart blood mitochondria: A comparison between middle-aged and young rats. Experimental Gerontology, 48(11), 1319-1322.

Marques, G. L., Neto, F. F., \& Oliveira, C. A. (2015). Oxidative damage in the aging heart: An experimental rat model. The Open Cardiovascular Medicine Journal, 9, 78-82.

Marzetti, E., Csiszar, A., \& Dutta, D. (2013). Role of mitochondrial dysfunction and altered autophagy in cardiovascular aging and disease: From mechanisms to therapeutics. American Journal of Physiology-Heart and Circulatory Physiology, 305(4), H459-H476.

Mdaki, K. S., Larsen, T. D., Weaver, L. J., \& Baack, M. L. (2016). Age related bioenergetics profiles in isolated rat cardiomyocytes using extracellular flux analyses. PLoS ONE, 11(2), 0149002.

Owada, T., Yamauchi, H., Saitoh, S., Miura, S., Machii, H., \& Takeishi, Y. (2017). Resolution of mitochondrial oxidant stress improves aged-cardiovascular performance. Coronary Artery Disease, 28(1), 33-43.

Payne, B. A., \& Chinnery, P. F. (2015). Mitochondrial dysfunction in aging: Much progress but many unresolved questions. Biochimica et Biophysica Acta, 1847(11), 1347-1353.

Prathima, S., \& Asha, D. S. (1999). Adaptations in lactate dehydrogenase and itsisozymes in aging mammalian myocardium: Interaction of exercise and temperature. Mechanisms of Ageing and Development, 108, 61-75.

Rodriguez, G., \& Lypez, M. (2014). Brain $\mathrm{Na}^{+}, \mathrm{K}^{+}$-ATPase activity in aging and disease. International Journal of Biomedical Science, 10(2), 85-102.

Rohit, B., Bhuwan, C. J., Ajudhiya, N. K., \& Atish, P. (2016). Antioxidant-rich fraction of Urtica dioica mediated rescue of striatal mito-oxidative damage in MPTP-induced behavioral, cellular, and neurochemical alterations in rats. Molecular Neurobiology, 54(7), 5632-5645.

Roya, D., Sudhir, K., Tomi-Pekka, T., \& Jyrki, K. V. (2017). Associations of estimated D-5-desaturase and D-6-desaturase activities with stroke risk 
factors and risk of stroke: The kuopio ischaemic heart disease risk factor study. British Journal of Nutrition, 117(4), 582-590.

Rudnyeva, Y. V., Nevzorov, V. P., Babiychuk, V. G., Chernyavskaya, E. A., \& Kulik, V. V. (2015) Features of changes of ultrastructure organization of myocardium cardiomyocytes and myocardium blood capillaries endotheliocytes in dynamics of aging in rats. Bulletin of Problems in Biology and Medicine, 4(2), 253258 (in Ukrainian).

Selyvanov, E. A., Hmilova, G. A., Beljaeva, Y. S., Slepneva, L. V., \& Sydorova, N. D. (1997). Sposob kolychestvennogo opredelenyja cytohroma C v preparatah, soderzhashhyh kollagen [Method of quantitative determination of cytochrome $\mathrm{C}$ in preparations containing collagen]. Patent of Russian Federation No 2084869, G01N21/25, application number 94023438/25 (in Russian).

Serova, D., Taran, O., \& Dyomshina, O. (2016). Biologichna aktyvnist’ preparativ na osnovi guminovyh rechovyn u pechinci pishhanok (Meriones unguiculatus) [Biological activity of humic substances in the liver of Mongolian gerbils (Meriones unguiculatus)]. Visnyk of Dnipropetrovsk University. Biology, Ecology, 24(2), 410-415 (in Ukrainian).

Shan, H., Yan, R., Diao, J., Lin, L., Wang, S., Zhang, M., Zhang, R., \& Wei, J. (2015). Involvement of caspases and their upstream regulators in myocardial apoptosis in a rat model of selenium deficiency-induced dilated cardiomyopathy. Journal of Trace Elements in Medicine and Biology, 31, 85-91.
Tepp, K., Puurand, M., \& Timohhina, N. (2017). Changes in the mitochondrial function and in the efficiency of energy transfer pathways during cardiomyocyte aging. Molecular and Cellular Biochemistry, 432, 141-158.

Tepp, K., Timohhina, N., Puurand, M., Klepinin, A., Chekulayev, V., Shevchuk, I., \& Kaambre, T. (2016). Bioenergetics of the aging heart and skeletal muscles: Modem concepts and controversies. Ageing Research Reviews, 28, 1-14.

Tosi, F., Sartori, F., \& Guarini, P. (2014). Delta-5 and delta-6 desaturases: Crucial enzymes in polyunsaturated fatty acid-related pathways with pleiotropic influences in health and disease. Advances in Experimental Medicine and Biology, 824, 61-81.

Vickers, A. E. M. (2009). Characterization of hepatic mitochondrial injuryinducedby fatty acid oxidation inhibitors. Toxicology Pathology, 37(1), 78-88.

Whitfield, J. B. (2001). Gamma glutamyl transferase. Critical Reviews in Clinical Laboratory Sciences, 38(4), 263-355.

Wieckowski, M. R., Giorgi, C., Lebiedzinska, M., Duszynski, J., \& Pinton, P. (2009). Isolation of mitochondria-associated membranes and mitochondria from animal tissues and cells. Nature Protocols, 4(11), 1582-1590.

Young, D. S. (2014). Effects on clinical laboratory tests: Drugs, disease, herbs and natural products, american association for clinical chemistry, John Wiley \& Sons, Inc.

Zhao, L., Zou, X., \& Feng, Z. (2014). Evidence for association of mitochondrial metabolism alteration with lipid accumulation in aging rats. Experimental Gerontology, 56, 3-12. 